formation mbH, D-76344 Eggenstein-Leopoldshafen (FRG) on quoting the depository number CSD-57479, the names of the authors, and the journal citation.

[11] The "linear" coordination of thallium in the $T]^{\mathrm{Hit}}$ compounds $\mathrm{R}_{2} \mathrm{TlH}$ al is in reality-as a result of the formation of Tl-Hal-Tl bridges-a sixfold coordination with trans R groups: H.-D. Hausen. E. Veigel, H.-J. Guder, Z. Naturforsch. 1974, 29h, 269; Y. M. Chow, D. Britton, Acta Crystallogr. Sect. $B$ 1975, 31, 1922. See also the analogous situation in $\mathrm{R}_{2} \mathrm{PbHal}_{2}: \mathrm{M}$. Matmmi, V. Busetti, A. Del Pra, Inorg. Chim. Acta 1967, 1, 419. Twofold coordination of $\mathrm{Tl}$ is rare. It is only observed when the occupation of additional coordination sites is prevented by steric shielding; the arrangement is then bent: $H$. W. Roesky, M. Scholz, M. Noltemeyer, F. T. Edelmann, Inorg. Chem. 1989, 28, 3829; C. Bianchini, D. Masi, K. Linn, C. Mealli, M. Peruzzini, F. Zanobini, ibid. 1992.31. 4036.

[12] L. M. Clarkson, W. Clegg. D. C. R. Hockless, N. C. Norman, T. B. Marder, J. Chem. Soc. Dalton Tians. 1991, 2229.

[13] O. J. Curnow, B. Schiemenz, G. Huttner, L. Zsolnai, J. Organomet. Chem.. 1993. 459. 17

[14] The term "-inidene" is be used in the following instead of the IUPAC classification "-andiyl".

[15] G. Huttner, Pule Appl. Chem. 1986, 58, 585; G. Huttner, K. Evertz, Acc. Chem. Res. 1986, 19,406

[16] B. Schiemenz, G. Huttner, unpublished results.

[17] F. Ettel. G. Huttner, L. Zsolnai, Angew. Chem. 1989, 101. 1525: Angew: Chem. Im. Ed. Engl. 1989, 28, 1496.

[18] 1. von Seyerl, U. Moering. A. Wagner, A. Frank, G. Huttner, Angess. Chem. 1978, 90, 911; Angew. Chem. Int. Ed. Engl. 1978, 17, 843.

[19] F. Bringewski, G. Huttner. W. Imhof, L. Zsolnai, J. Organomet. Chem. I992, 439, 33

[20] J. M. Cassidy, K. H. Whitmire, Inorg. Chem. 1989, 28, 1432, 1435: K. H. Whitmire. J. M. Cassidy, A. L. Rheingold. R. R. Ryan, ibid. 1988, 27. 1347. K. H. Whitmire, R. R. Ryan. H. J. Wasserman. T. A. Albright. S.-K. Kang. J. Am. Chem. Soc. 1986, 108,6831.

\section{The Bis(cyclopentadienyl)thallate(I) Anion Isoelectronic with Stannocene **}

By David R. Armstrong, Regine Herbst-Irmer, Annja Kuhn, David Moncrieff, Michael A. Paver, Christopher A. Russell, Dietmar Stalke, Alexander Steiner, and Dominic S. Wright*

We have recently shown that a range of tri(cyclopentadienyl)stannate and -plumbate complexes consisting of discrete, "ion-separated" ion pairs and bridged, "contacted" ion pairs can be prepared by nucleophilic addition reactions of $\left[\mathrm{Cp}_{2} \mathrm{Mg}\right]$ and $[\mathrm{CpNa}]$ to $\left[\mathrm{Cp}_{2} \mathrm{E}\right]\left(\mathrm{Cp}=\mathrm{C}_{5} \mathrm{H}_{5} ; \mathrm{E}=\mathrm{Sn}\right.$,

[*] Dr. D. S. Wright, M. A. Paver, C. A. Russell

University Chemical Laboratory

Lensfield Road, GB-Cambridge CB21EW (UK)

Telefax: Int. code $+(223) 3363-62$

Priv.-Doz. Dr. D. Stalke; Dr. R. Herbst-Irmer, A. Kuhn, A. Steiner

Institut für Anorganische Chemie

Tammannstrasse 4, D-37077 Göttingen (FRG)

Telefax: Int. code $+(551) 39-2582$

Dr. D. Moncrieff

Supercomputer Computations Research Institute B-186

Florida State University

Tatlahasee. FL 32 306-4052 (USA)

Dr. D. Armstrong

Department of Pure and Applied Chemistry

Thomas Graham Building

295 Cathedral Street, GB-Glasgow G1 1XL (UK)

[**] We thank the British Science and Engineering Research Council (M.A.P.. C.A.R., D.S.W.), the Royal Society (D.S.W.), the Nuffield Foundation (D.S.W), the Associated Octel Co. Ltd. (M.A.P. D.S.W.), the Deutsche Forschungsgemeinschaft and the Fonds der Chemischen Industrie (A.S.. D.S.; fellowship for A.K.), and the U.S. Department of Energy (no. DEFC05-85ER 2500000) (D.M.). We also thank SciAm for the use of their graphics package and software and Riedel-de Häen for providing the perfluorinated polyether used in mounting the crystal for the structure determination.
$\mathrm{Pb} .^{[1-3)}$ In all these derivatives the heavy $\mathrm{p}$ block metals behave as acceptors rather than donating their electron pairs. In the $\mathrm{Pb}$ complexes ${ }^{[3]}\left[\left(\eta^{5}-\mathrm{Cp}\right)_{2} \mathrm{~Pb}\left(\mu-\eta^{5}-\mathrm{Cp}\right) \mathrm{Na}\right.$. PMDETA] [PMDETA $\left.=\left(\mathrm{Me}_{2} \mathrm{NCH}_{2} \mathrm{CH}_{2}\right)_{2} \mathrm{NMe}\right]$ and $\left[\left\{\left(\eta^{3}-\mathrm{Cp}\right) \mathrm{Pb}^{-}\right\}_{2} \cdot \mathrm{Mg}(\mathrm{THF})_{6}^{2+}\right]$, the $\left[\mathrm{Cp}_{3} \mathrm{~Pb}\right]^{-}$ions can be seen as extruded fragments of the polymeric zig-zag chain structure of orthorhombic $\left[\mathrm{Cp}_{2} \mathrm{~Pb}\right]_{x}{ }^{[4]}$ With this in mind, we have turned our attention to cyclopentadienyl complexes with elements of Group $13(\mathrm{E}=\mathrm{Ga}$, In, TI). The solid-state structures of [CpIn] and [CpTl] are both known and display polymeric zig-zag chains, $\left[\left(\mu-\eta^{5}-\mathrm{Cp}\right) \mathrm{E}\right]_{x}$, in which the metal centers again behave as acceptors to the bridging $\mathrm{Cp}$ ligands. ${ }^{[5]}$ We wondered whether complexes containing $\left[\mathrm{Cp}_{2} \mathrm{E}\right]^{-}$units could be prepared by addition of $\mathrm{Cp}^{-}$to Group 13 metallocenes.

We report the syntheses and structures of the ion-separated complex 1 and of the contacted complex 2. ${ }^{[6]}$ Both com-

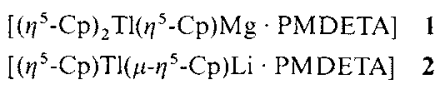

plexes contain bent $\left[\left(\eta^{5}-\mathrm{Cp}\right)_{2} \mathrm{Tl}\right]^{-}$ions which are isoelectronic and isostructural with the 14-electron complex stannocene.

Complex 1 is prepared by stirring a mixture of $[\mathrm{CpTl}]$ and $\left[\mathrm{Cp}_{2} \mathrm{Mg}\right](1: 1 \mathrm{~mol}$ ratio $)$ in THF. Addition of PMDETA ( 1 mol equiv) produces a colorless precipitate of 1 which is recrystallized from THF. Similar reaction of [CpTl] and [CpLi] $(1: 2 \mathrm{~mol}$ ratio) in THF, followed by addition of PMDETA (1 mol equiv), produces 2 (see Experimental Procedure).

An X-ray crystallographic study on complex $1^{[6]}$ shows a structure with discrete ion pairs (Fig. 1). The unit cell con-
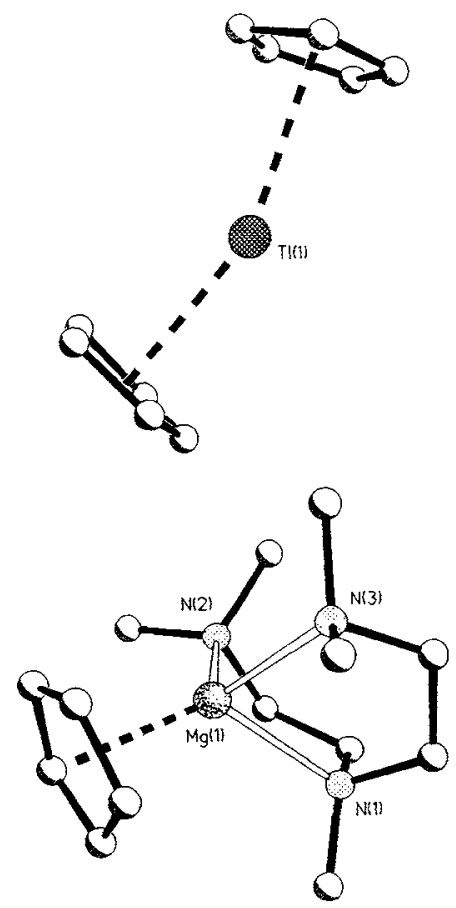

Fig. 1. Molecular structure of 1 . Hydrogen atoms have been omitted for clarity. Selected distances $[\AA]$ : Anion 1 : $\mathrm{Tl}(1)-\mathrm{C}(1) 2.86(3)$, Tl(1)-C(2) 2.91(3), Tl(1)C(3) 2.99(3). Tl(1)-C(4) 3.07(4). TI(1)-C(5) 2.85(3). Tl(1)-C(6) 3.05(3). Tl(1)C(7) 3.04(3). Tl(1)-C(8) 2.94(2). Tl(1)-C(9) 2.93(3). Tl(1)-C(10) 2.88(3). Anion 2: $\mathrm{Tl}(2)-\mathrm{C}(11) 3.02(3), \mathrm{Tl}(2)-\mathrm{C}(12) 2.94(3)$, $\mathrm{Tl}(2)-\mathrm{C}(13) 2.93(3) . \mathrm{Tl}(2)-\mathrm{C}(14)$ 2.98(3), Tl(2)-C(15) 3.09(3), Tl(2)-C(16) 2.93(3), Tl(2)-C(17) 2.87(3). Tl(2)C(18) 2.92(3), Tl(2)-C(19) 3.03(3), Tl(2)-C(20) 3.03(3). Averages over all molecules in the unit cell: $\mathrm{Tl}-\mathrm{Cp}$ (centroid) 2.72. $\mathrm{Mg}-\mathrm{N} 2.20, \mathrm{Mg}-\mathrm{Cp}$ (centroid) 2.08. Cp (centroid)-Tl-Cp (centroid) $156.7^{\circ}$. 
sists of two independent $\left[\left(\eta^{5}-\mathrm{Cp}\right)_{2} \mathrm{Tl}\right]^{-}$ions and two independent $\left[\left(\eta^{5}-\mathrm{Cp}\right) \mathrm{Mg} \cdot \mathrm{PMDETA}{ }^{+}\right]$ions. The structure of $\mathbf{2}$ contains two independent contacted ion pairs in the solid state (Fig. 2), in which one Cp ligand bound to Tl is additionally involved with a Lewis base solvated $\mathrm{Li}^{+}$ion (av $\mathrm{Li}-$ $\left.\mathrm{Cp}(\mathrm{b})_{\text {centroid }} 2.25 \AA\right)$ as a $(\mu-\mathrm{Cp})$ bridge. ${ }^{[6]}$ All the independent $\left[\left(\eta^{5}-\mathrm{Cp}\right)_{2} \mathrm{Tl}\right]^{-}$units of 1 and 2 are bent, with a mean $\mathrm{Cp}-\mathrm{Tl}-\mathrm{Cp}$ angle (from the centroids of the $\mathrm{Cp}$ ligands) of $156.7^{\circ}$ in 1 and $153.3^{\circ}$ in 2 . These angles can be compared to the average centroid Cp-E-Cp angle of $146^{\circ}$ for the two independent bent molecules of $\left[\mathrm{Cp}_{2} \mathrm{Sn}\right]$ in the solid state ${ }^{[10]}$ and approximately $135^{\circ}$ for $\left[\mathrm{Cp}_{2} \mathrm{~Pb}\right]$ in the gas phase, ${ }^{[11]}$ with which the 14-electron thallate ions in $\mathbf{1}$ and $\mathbf{2}$ are isostructural and isoelectronic. The $\mathrm{Cp}-\mathrm{Tl}-\mathrm{Cp}$ angle in polymeric $\left[\left(\eta^{5}-\mathrm{Cp}\right) \mathrm{Tl}\right]_{x}$ is significantly more acute (ca. $137^{\circ}$ ) than those observed in the $\left[\left(\eta^{5}-\mathrm{Cp}\right)_{2} \mathrm{Tl}\right]^{-}$ions of both complexes. $^{[5]}$

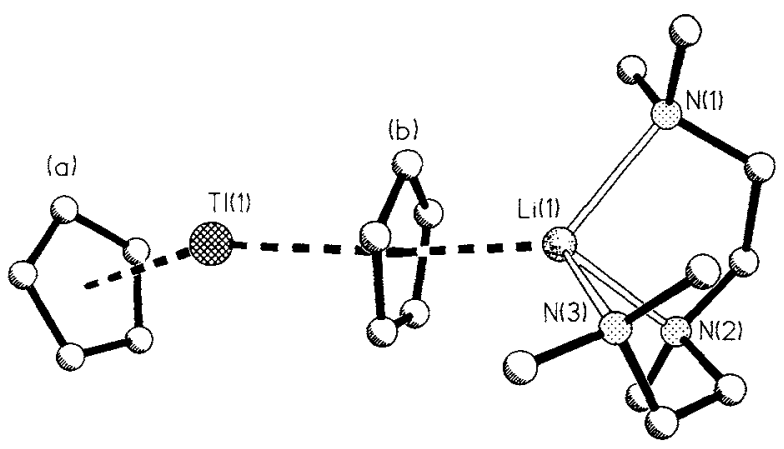

Fig. 2. Molecular structure of 2. Hydrogen atoms have been omitted for clarity Selected distances $[\AA]$ : Molecule 1: TI(1)-C(11) 3.02(1), TI(1)-C(12) 3.07(1), $\mathrm{Tl}(1)-\mathrm{C}(13) \quad 3.20(1)$, Tl(1)-C(14) 3.19(1), Tl(1)-C(15) 3.10(1), Tl(1)-C(16) 2.81(1). Tl(1)-C(17) 2.86(1). Tl(1)-C(18) 2.89(1), $\mathrm{Tl}(1)-\mathrm{C}(19) 2.89(1)$, $\mathrm{Tl}(1)-$ C(12) $2.82(1), \mathrm{Li}(1)-\mathrm{C}(11) 2.69(2), \mathrm{Li}(1)-\mathrm{C}(12) 2.53(2), \mathrm{Li}(1)-\mathrm{C}(13) 2.34(2)$. Li(1)-C(14) 2.42(2), Li(1)-C(15) 2.62(2). Molecule 2: Tl(2)-C(21) 3.00(1), Tl(2)$\mathrm{C}(22) 3.04(1), \mathrm{Tl}(2)-\mathrm{C}(23) 3.13(1), \mathrm{Tl}(2)-\mathrm{C}(24) 3.10(1), \mathrm{Tl}(2)-\mathrm{C}(25) 3.03(1)$, $\mathrm{Tl}(2)-\mathrm{C}(26) \quad 2.82(1), \mathrm{Tl}(2)-\mathrm{C}(27) \quad 2.86(1), \mathrm{Tl}(2)-\mathrm{C}(28) 2.91(1), \mathrm{Tl}(2)-\mathrm{C}(29)$ 2.90(1). $\mathrm{Tl}(2)-\mathrm{C}(30) 2.86(1), \mathrm{Li}(2)-\mathrm{C}(21) 2.68(2), \mathrm{Li}(2)-\mathrm{C}(22) 2.61(2), \mathrm{Li}(2)-$ C(23) 2.45(2), Li(2)-C(24) 2.46(2). Li(2)-C(25) 2.59(2). Averages over all molecules in the unit cell: Tl-Cp(a) (centroid) 2.61, Tl-Cp(b) (centroid) 2.85, Li$\mathrm{Cp}$ (b) (centroid) 2.25, Li-N 2.23, $\mathrm{Cp}$ (a) (centroid)-Tl- $\mathrm{Cp}(\mathrm{b})$ (centroid) 153.3, $\mathrm{Cp}$ (a) (centroid)-Li-Cp(b) (centroid) 175.7 .

While the $\mathrm{Tl}$ center of the discrete $\left[\left(\eta^{5}-\mathrm{Cp}\right)_{2} \mathrm{Tl}\right]^{-}$ion in 1 is attached almost equivalently to the two $\eta^{5}$-Cp ligands (av $\mathrm{Tl}-\mathrm{C} \mathrm{p}_{\text {centroid }} 2.72 \AA$ ), in 2 the terminal $\eta^{5}$ - $\mathrm{Cp}$ contact (av $\left.\mathrm{Tl}-\mathrm{Cp}(\mathrm{a})_{\text {centroid }} 2.60 \AA\right)$ is significantly shorter than that made with the $\mathrm{Li}^{+}$-bridging $\mu$-Cp ligand (av $\mathrm{Tl}-\mathrm{Cp}(\mathrm{b})_{\text {centroid }}$ $2.85 \AA$ ). In 2 , the $\mathrm{Li}^{+}$ion competes with $\mathrm{Tl}$ for the electron density on the bridging $C p$ ligand. The $C p$ ligand is "dragged" away from the Tl center, and there is a compensatory enhancement in the interaction between the terminal $\eta^{5}-\mathrm{Cp}$ ligand and $\mathrm{Tl}$; the $\mathrm{Tl}-\mathrm{Cp}(\mathrm{a})_{\text {centroid }}$ distance approaches that found in the gas-phase structure of monomeric $\left[\left(\eta^{5}-\mathrm{Cp}\right) \mathrm{Tl}\right]$ (ca. $\left.2.41 \AA\right) .{ }^{[12]}$ Similarly to the bridging $\mu-\eta^{5}-\mathrm{Cp}$ ligand found in $\left[\left(\eta^{5}-\mathrm{Cp}\right)_{2} \mathrm{E}\left(\mu-\eta^{5}-\mathrm{Cp}\right)\right.$ $\mathrm{Na} \cdot \mathrm{PMDETA}](\mathrm{E}=\mathrm{Sn}, \mathrm{Pb})$, the $\mu$-Cp bridge of 2 is bent (av $\mathrm{Tl}-\mathrm{Cp}(\mathrm{b})_{\text {centroid }}-\mathrm{Li} 175.2^{\circ}$, cf. ca. $172^{\circ}$ in $\left[\left(\eta^{5}-\mathrm{Cp}\right)_{2} \mathrm{E}\left(\mu-\eta^{5}-\mathrm{Cp}\right)\right.$ $\mathrm{Na} \cdot \mathrm{PMDETA}])^{[1-3]}$

Complexes 1 and 2 are only the second examples of monomeric $\mathrm{Cp}$ thallium(I) species characterized in the solid state; the only other known monomeric complex is $\left[\mathrm{TlC}_{5}\left(\mathrm{CH}_{2} \mathrm{Ph}\right)_{5}\right]^{\left[{ }^{[3]}\right.}$ Almost all structurally characterized $\mathrm{Cp}$-based derivatives of thallium so far have had polymeric structures akin to that of $\left[\left(\eta^{5}-\mathrm{Cp}\right) \mathrm{Tl}\right]_{\infty} \cdot{ }^{15]}$ Additionally, 1 and $\mathbf{2}$ are the only structurally characterized unsubstituted $\mathrm{Cp}$ derivatives apart from $\left[\left(\eta^{5}-\mathrm{Cp}\right) \mathrm{Tl}\right]_{x}$. The closest structural analogue to $\mathbf{1}$ and $\mathbf{2}$ is the dimeric ring complex $\left[\left\{\mathrm{TlAu}\left(\mathrm{C}_{5} \mathrm{H}_{4} \mathrm{PPh}_{2}\right)_{2}\right\}_{2}\right]$, in which essentially linear $\left[\mathrm{C}_{5} \mathrm{H}_{4} \mathrm{PPh}_{2}-\mathrm{Au}-\mathrm{C}_{5} \mathrm{H}_{4} \mathrm{PPh}_{2}\right]$ units are linked together through $\eta^{5}-\mathrm{Cp}$ contacts to $\mathrm{Tl}^{\mathrm{I}}\left(\mathrm{Cp}_{\text {centroid }}-\mathrm{Tl}-\mathrm{C} \mathrm{p}_{\text {centroid }} \mathrm{ca}\right.$. $\left.135^{\circ}\right) .^{[14]}$ In view of our results this complex can be reinterpreted as an ion-contacted gold thallate complex rather than the implied Tl-contacted gold diphosphide, although there is some ambiguity as to the charge distribution in the ligand.

To our knowledge, $\left[\left(\eta^{5}-\mathrm{Cp}\right) \mathrm{Mg} \cdot \mathrm{PMDETA}\right]^{+}$of $\mathbf{1}$ is the first example of a mononuclear cationic fragment derived from $\left[\mathrm{Cp}_{2} \mathrm{Mg}\right]^{\left[{ }^{[5]}\right.} \mathrm{It}$ is interesting to note that, although its bonding is largely ionic, the cation is formally isoelectronic with the 12-electron compound $\left[\mathrm{Cp}_{2} \mathrm{Mg}\right]$.

$\mathrm{Ab}$ initio $\mathrm{MO}$ calculations were performed on various isomers of the discrete $\left[\mathrm{Cp}_{2} \mathrm{Tl}\right]^{-}$ion in 1 at the Hartree-Fock level and with electron correlation. ${ }^{[16,17]}$ Initially minimum basis set (MBS) calculations were performed on different $\mathrm{Cp}$ ring conformations, to assess the relative stabilities of the "linear" and "bent" models. The most stable bent $C_{s}$ conformer (I), the same as that observed for the $\left[\mathrm{Cp}_{2} \mathrm{Tl}\right]^{-}$ion in $\mathbf{1}$ in the solid state, and the most stable linear $D_{5 d}$ conformer (II) were then optimized using the ECP-DZ basis set. Their geometries and that of [CpTl] (III) are shown in Figure 3. The
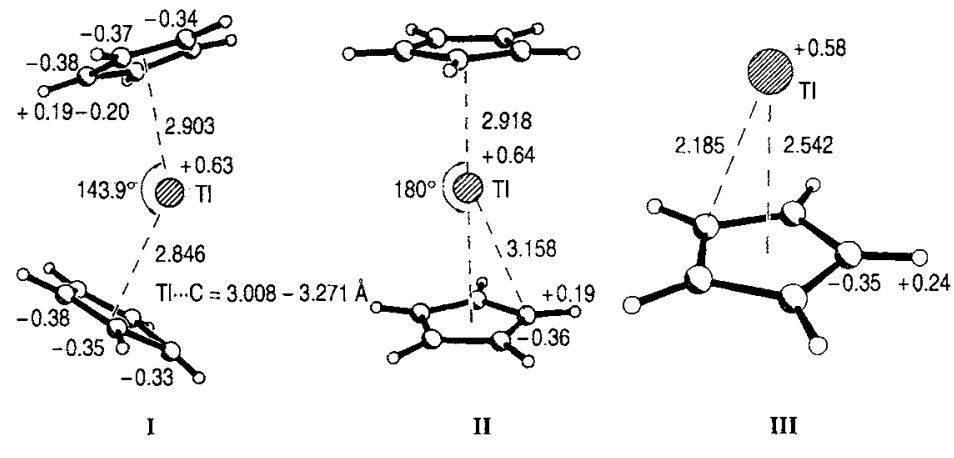

Fig. 3. Optimized geometries (DZ basis set) of the $\left[\mathrm{Cp}_{2} \mathrm{Tl}\right]^{-}$ion-the bent structure with $C_{s}$ symmetry (I) and the linear structure with $D_{s i d}$ symmetry (II)-and that of monomeric [CpTl] (III).

energy for the association of $\mathrm{Cp}^{-}$and $[\mathrm{CpTl}]$ is reasonably favorable $\left(-6.38 \mathrm{kcal} \mathrm{mol}^{-1}\right.$ to give the most stable bent structure I). ${ }^{[17]}$ Although the $\mathrm{Cp}-\mathrm{Tl}$ contacts are significantly elongated in I and II compared to the $\mathrm{Cp}-\mathrm{Tl}$ distance in III, there is little difference either in the charge carried by the $\mathrm{Cp}$ ring atoms or in the charge on the $\mathrm{Tl}$ center. Bending of the linear structure II producing I slightly enhances the Cp$\mathrm{Tl}$ interactions but has only a marginal effect on the charge distribution within the molecule. However, whereas in II the $\mathrm{Cp}$ ligands are symmetrically attached to $\mathrm{Tl}\left(\mathrm{Cp}_{\text {centroid }}\right.$ Tl $2.918 \AA$ ), in I one of the Cp ligands is closer to the metal than the other is ( $\left.\mathrm{Cp}_{\text {centroid }}-\mathrm{Tl}\right) 2.846$ and $2.903 \AA$ ).

The optimized geometries (DZ basis set) of the linear and bent isomers of $[\mathrm{Cp}, \mathrm{Tl}]^{-}$were employed in a series of calculations with electron correlation. The results (MP2, MP3, MP4) confirm that the bent geometry is only slightly more stable than its linear counterpart; at the MP 4 level the difference in energy is $0.82 \mathrm{kcal} \mathrm{mol}^{-1} .^{[17]}$ This finding is contrary 
to that calculated for the 14-electron complex $\left[\mathrm{Cp}_{2} \mathrm{Ge}\right]$ and to the general concensus concerning $\left[\mathrm{Cp}_{2} \mathrm{Sn}\right],{ }^{[18-20]}$ which proposes that bent structures are preferred on electronic grounds since bending presumably stabilizes the lone pair in the antibonding $a_{1 \mathrm{~g}}^{*}$ molecular orbital as a consequence of the admixing of this orbital with the metal $p_{x}$ atomic orbital. Overall, the calculations on $\left[\mathrm{Cp}_{2} \mathrm{Tl}\right]^{-}$indicate that the geometry of the thallocene anion is highly flexible. Orbital admixing appears to be ineffective here and a largely spherical lone pair orbital is present. This feature is illustrated in Figure 4 where, in addition, it can be seen that there is a constriction in the electron density between $\mathrm{Tl}$ and the more weakly attached $\mathrm{Cp}$ ligand.

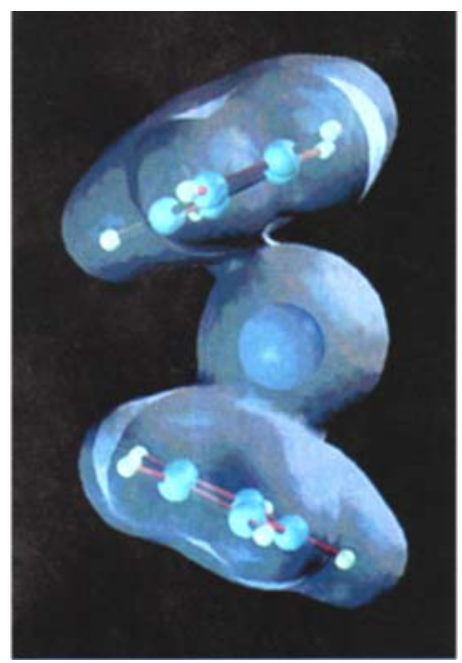

Fig. 4. One of the isosurfaces of electron density for the bent structure of $\left[\mathrm{Cp}_{2} \mathrm{TI}\right]^{-}$having $C_{s}$ symmetry (geometry optimization with the $\mathrm{DZ}$ basis set).

\section{Experimental Procedure}

1: [CpTI] $(0.538$ g. $2.0 \mathrm{mmol})$ was stirred with $[\mathrm{Cp}, \mathrm{Mg}](0.308 \mathrm{~g} .2 \mathrm{mmol})$ in $10 \mathrm{~mL}$ THF. The reactants dissolved giving a golden brown solution. On addition of PMDETA $(0.42 \mathrm{~mL} .2 \mathrm{mmol})$ a pink solid precipitated. which dissolved on heating the reaction mixture to reflux. The reaction mixture was filtered and cooled slowly $\left(12 \mathrm{~h}\right.$ at $\left.20^{\circ} \mathrm{C}\right)$ to give air-sensitive, light-pink crystals of 1 . Yield $0.360 \mathrm{~g}(30 \%)$ over two batches: decomp $120 \mathrm{C}$ to black solid: IR (Nujol) $i=3059 \mathrm{~cm}^{-1}(\mathrm{Cp}-\mathrm{H}) ;{ }^{1} \mathrm{H} \mathrm{NMR}\left(+25^{\circ} \mathrm{C}, 400 \mathrm{MHz} .\left[\mathrm{D}_{8}\right] \mathrm{THF}\right): \delta=5.66(\mathrm{~s}$, $15 \mathrm{H} ; \mathrm{CpH}), 2.41\left(\mathrm{~s}, 3 \mathrm{H} ; \mathrm{CH}_{3} \mathrm{~N}\right), 2.34\left(\mathrm{~s}, 12 \mathrm{H} ;\left(\mathrm{CH}_{3}\right)_{2} \mathrm{~N}\right), 2.11(\mathrm{~s}, 8 \mathrm{H}$; $\left.\left(\mathrm{CH}_{3}\right\}_{2}\right):{ }^{13} \mathrm{C} \mathrm{NMR}\left(+25 \mathrm{C} .100 .6 \mathrm{MHz},\left[\mathrm{D}_{8}\right] \mathrm{THF}\right): \delta=107.0\left(\mathrm{C}_{3} \mathrm{H}_{5}\right), 55.0-$ $59.0\left(\mathrm{CH}_{3} \mathrm{~N}\right.$ and $\left.\left(\mathrm{CH}_{3}\right)_{2} \mathrm{~N}\right), 46.0-49.0\left(\mathrm{CH}_{2}\right)_{2}$; correct $\mathrm{C}, \mathrm{H}, \mathrm{N}$ analysis.

2: [CpTl] $(0.538$ g. $2.0 \mathrm{mmol})$ was stirred with [CpLi] $(0.288 \mathrm{~g}, 4 \mathrm{mmol})$ in $10 \mathrm{~mL}$ THF. The solid dissolved giving a yellow solution which was filtered before PMDETA $(0.42 \mathrm{~mL} .2 \mathrm{mmol})$ was added. Cooling of the resulting solution $(2 \mathrm{~d}$ at $-35 \mathrm{C})$ gave air-sensitive. colorless crystals of $\mathbf{2}$. The crystals melt and/or redissolve below $0 \mathrm{C}$, and all attempts to isolate them were unsuccessful. $\mathbf{2}$ could only be characterized by low-temperature X-ray crystallography $[7]$.

Received: June 11, 1993 [Z 6134 IE] German version: Angew. Chem. 1993. 105, 1807
[6] Crystal data for 1: $\mathrm{C}_{24} \mathrm{H}_{38} \mathrm{~N}_{3} \mathrm{MgTl}, M=597,3$, monoclinic, space group $P 2, / c, a=15.129(3), b=15.483(4), c=21.090(4) \AA, \alpha=7=90 \%, \beta=$ $90.02(3), V=4.940 \mathrm{~nm}^{-3}, Z=8, \rho_{\mathrm{cuicu}}=1.606 \mathrm{Mgm}^{-3}, i=0.71073 \AA$ $T=-120 \circ \mathrm{C}, \mu\left(\mathrm{Mo}_{\mathrm{kx}}\right)=6.578 \mathrm{~mm}^{-1}$. Data were collected on a SiemensStoe AED diffractometer using an oil-coated, rapidly cooled crystal of dimensions $0.2 \times 0.2 \times 0.2 \mathrm{~mm}$ in an oil drop [7] by the $20 i \omega$ method $(8 \leq 20 \leq 45)$. Of a tota! of 13787 collected reflections, 6434 were independent. The data were corrected for absorption by a semiempirical method based on $\psi$ scans. The structure was solved by Patterson methods (SHELXS-90)[8] and refined by full-matrix least-squares on $F^{2}[9]$ to final values of $R 1 \quad(F>4 \sigma(F))=0.083$ and $w R 2=0.193$ (all data) $\left.\left[R 1=\sum\left|F_{0}-F_{\mathrm{c}}\right| / \sum F_{0} \text { and } w R 2=\left(\sum w\left(F_{\mathrm{v}}^{2}-F_{\mathrm{c}}^{2}\right)^{2} \sum \sum \mathrm{H}_{\mathrm{u}}\right)^{2}\right)^{0.5}\right] ;$ largest peak and hole in the final difference Fourier map were 4.152 and $-2.218 \mathrm{e} \AA^{-3}$. The structure was successfully refined as a twin, in which the monoclinic angle. very close to $90 \%$, shows orthorhombic symmetry to be cmulated. The twinning factor $B$ refines to 0.488 (C. S. Pratt, B. A. Coyle, J. A. Ibers, J. Chem. Soc. A. 1971, 2146-2152). Crystal data for 2 $\mathrm{C}_{19} \mathrm{H}_{33} \mathrm{LiN}_{3} \mathrm{Tl}, \quad M=514.79$. monoclinic, space group $P 2, i c, a=$ 13.390(3), $b=25.604(6), c^{\prime}=13.390(3) \AA . \alpha=\because=90^{\circ}, \beta=112.39(3)^{\prime}$ $V=4245(2) \AA^{-3}, \quad Z=8, \quad \rho_{\text {caled }}=1.611 \mathrm{Mg} \mathrm{m}^{-3}, \quad j=0.71073 \AA . T=$ $-120 \mathrm{C}, \mu\left(\mathrm{Mo}_{\mathrm{k} t}\right)=7.615 \mathrm{~mm}^{-1}$. Data were collected on a Siemens-Stoe AED diffractometer using an oil-coated. rapidly-cooled crystal of dimensions $0.2 \times 0.1 \times 0.1 \mathrm{~mm}$ in an oil drop [7] by the $20 ; \omega$ method $(8 \leq 20 \leq 45)$. Of a total of 17661 collected reflections, 5644 were independent. The data were corrected for absorption by a semiempirical method based on $\Psi$ scans. The structure was solved by Patterson nethods (SHELXS-90) [8] and refined by full-matrix least-squares on $F^{2}$ [9] to final values of $R 1(F>4 \sigma(F))=0.043$ and $1 \cdot R 2=0.112$ (all data) $\mid R 1=$ $\sum\left|F_{0}-F_{c}\right| / \sum F_{0}$ and $\left.11 R 2=\left(\sum w\left(F_{0}^{2}-F_{c}^{2}\right)^{2} \sum w\left(F_{0}^{2}\right)^{2}\right)^{0.5}\right\}$; largest peak and hole in the final difference Fourier map were 2.117 and $-1.887 \mathrm{eA}$. The struct ure was successfully refined as a twin. Since $a$ and $c$ are the same length orthorhombic symmetry is shown to be emulated. The twinning factor $B$ refines to 0.474(1) (C. S. Pratt, B. A. Coyle. I. A. Ibers, J. Chem Sox. A. 1971, 2146-2152). Further details of the crystal structure investgations are available on request from the Director of the Cambridge Crystallographic Data Centre, 12 Union Road. GB-Cambridge, CB2 1EZ, on quoting the full journal citation.

[7] T. Kottke, D. Staike, J. Appl. Crutallogr. 1993. 26. 615-619.

[8] G. M. Sheldrick, Acta Crystaltogr. Sect. A 1990, 46, 467-473.

[9] G. M. Sheldrick, SHELXL-93, Göttingen, 1992.

[10] a) First synthesis: E. O. Fischer, H. Grüber, Z. Nalurforsch, $B, 1956,11$, 1182: b) Structure analysis: J. L. Atwood, W. E. Hunter, A. H. Cowley, R. A. Jones. C. A. Stewart, $J$. Chem. Soc. Chem. Commun. 1981, 925-927.

[11] A. Almenningen. A. Haaland. T. Motzfeld, J. Organomet. Chem. 1967, 7 , 97- 104 .

[12] J. K. Tyler, A, P. Cox. J. Sheridan, Nature 1959. 183. 1182.

[13] H. Schumann. C. Janiak, M. A. Khan. J. J. Zuckermann. J. Organomet. Chem. 1988, 354, 7--13

[14] G. K. Anderson. N. P. Rath. J. Organomet. Chem. 1991, 414, 129-135.

[15] W. Bünder, E. Weiss, J. Organomet. Chem. 1975, 92. 1-6.

[16] M. J. Frisch. G. W. Trucks, P. M. Head-Gordon, P. M. W. Gill, M. W Wong. J. B. Forseman, B. G. Johnson, H. B. Schleger, M. A. Robb, E. S. Replogle, R. Gomperts, J. L. Andres, K. Raghavachari, J. S. Binkley, C. Gonzalcz, R. L. Martin. D. Fox, D. J. Defrees. J. Baker, J. J. P. Stewart. J. A. Pople, Gaussian 92, Gaussian Inc., Pittsburgh, PA, 1992.

[17] Calculational data for $\left[\mathrm{Cp}_{2} \mathrm{Tl}^{-}:\right.$An Effective Core Potential (ECP) basis set was used for $\mathrm{Tl}$ in all calculations (P. I. Hay and W. R. Wadte, J. Chem Phys. 1985, 82,270, 284, and 299). Absolute energies $E$ in atomic units and relative energies [ $\mathrm{kcal} \mathrm{mol}^{-1}$ ] in parentheses: MBS, bent $C_{2 v}(x)$ ("toe-totoe" $C$ p arrangement) $E=-429.834961(0.25)$, bent $C_{s}$ (model $\left.\mathbf{I}\right) E=$ $-429.835351(0.0)$. bent $C_{2 r}(\beta)$ ("heel-to-heel" $C p$ arrangement) $E=$ - $429.835305(0.0)$, linear $D_{5 n} E=-429.827620$ (4.85), linear $D_{5 d}(\bmod -$ el II) $E=-429.827622(4.85)$. DZ, model II $E=-434.530730(0.70)$, model I $E=-434.531859(0.0)$, CpTl $E=-242.341708 . \mathrm{Cp}^{-} E=$ -192.145581. MP2, model II $E=-435.483388(0.73)$, model I $E=$ $-435.484498(0.0)$, MP 3, Model II $E=-435.532835$ (0.37), model I $E=-435.533421(0.0)$. MP4, model II $E=-435.5881261 \quad(0.82)$, model I $E=-435.589433(0.0)$.

[18] C. Elschenbroich. A. Salzer. Organometallchemie, 2nd ed.. Teubner, Stuttgart, 1988; Organometallics, 1st ed., VCH, Weinheim, 1988, p. 134.

[19] P. Jutzi, Adv. Organomet. Chem. 1986, 26, 217-285.

[20] J. Almlöf. L. Fernholt. K. Faegri, Jr., A. Haaland. B. E. R. Schilling, R. Seip. K. Taugløl. Acta Chem. Scand. Ser. A 1983, 37. 131-140.

[1] M. G. Davidson, D. Stalke, D. S. Wright, Angew. Chem. 1992, 104, 1265 1266: Angest Chem lhit El Engl 1992, 3t, 1226-1227.

[2] A. J. Edwards, M. A. Paver. P. R. Raithby. C. A. Russell. D. Stalke. D. S. Wright, J. Chem. Soc. Dalton Tians. 1993, 1465-1466.

[3] D. R. Armstrong, M. G. Davidson, D. Moncrieff, C. A. Russell, D. Stalke, A. Steiner, D. S. Wright, J. Am. Chem. Soc, submitied.

[4] C. Panattoni, G Bombieri, U. Croato, Acta Crystallogr. Sect. A 1966, 21. $823-826$.

[5] C. Panattoni, E. Frasson. F. Menegus, Nature 1963, 199, 1087 1089. 